\title{
THE RELEVANCE AND IMPACT OF SOUTH AFRICAN LABOUR LAW IN THE MINING SECTOR: A FOURTH INDUSTRIAL REVOLUTION PERSPECTIVE
}

\author{
Faheemah Karolia-Hussain \\ BCom LLB LLM \\ University of Johannesburg \\ Elmarie Fourie \\ BProc LLM LLD \\ HOD: Department of Public Law, Senior Lecturer \\ University of Johannesburg
}

\section{SUMMARY}

The mining sector is one of the contributors to the South African economy and improving productivity is important if it is to remain competitive in the global marketplace. Thus, the technologies that will be created by the Fourth Industrial Revolution (4IR) are important to the mining sector. However, if this leads to mining companies being less reliant on labour, then these changes will have a negative impact on the jobs of mineworkers.

This article looks at the legal framework that governs the mining sector in South Africa in the context of 4IR. The Labour Relations Act (LRA) provides for collective bargaining and strike action, but collective bargaining in the South African mining sector is failing and has not produced the desired result. Strike action has become more common and strikes are often violent and unprotected. Secondly, occupational health and safety risks are present in the mines despite protective legislation namely, the Mine Health and Safety Act (MHSA). Workers experience harsh working conditions underground. Lastly, workers' skills need to be developed if they are to retain their jobs in 4IR. In terms of legislation, workers should receive training if such training is available for their sector. Consideration urgently needs to be given to the impact on and relevance of 4IR to the labour legal framework in the mining sector. Furthermore, changes to the law in readiness for 4IR and its impact on the workforce in the mines should be considered. 


\section{$1 \quad$ INTRODUCTION}

Work is an important part of a person's life because generally it helps meet a person's needs and enables a decent life. ${ }^{1}$ However, it may also be dangerous, especially for employees in the mining sector. ${ }^{2}$ The Fourth Industrial Revolution (4IR) is the latest phase in technological change taking place around us that has an impact on the workplace, including in the mining sector. ${ }^{3}$ Technological advance impacts on productivity in a positive way $;^{4}$ machines perform at a constant quality and work continuously. ${ }^{5}$ Thus, industries that employ workers to perform repetitive tasks choose automation over a human labour force. ${ }^{6}$ Automation reduces costs and provides a more pleasant work environment by providing safer working conditions. ${ }^{7}$ The mining sector is a significant contributor to the South African economy $;{ }^{8}$ it employs 436000 individuals. ${ }^{9}$ Many of the workers are from poverty-stricken communities. ${ }^{10}$ Automation may result in further job losses in the mining sector, ${ }^{11}$ meaning that labour regulation in the mining sector in South Africa needs reconsideration. Legislation plays an important part in shaping labour relations, especially with regard to occupational health and safety, collective bargaining and strike action, and skills development. ${ }^{12}$ Workers need to participate in collective bargaining related to work-related matters that are impacted by 4IR. However, the current collective bargaining system is inefficient. ${ }^{13}$ Additionally, there is a need for preventive

1 International Labour Organisation (ILO) Global Commission on the Future of Work: Work for a Brighter Future (2019) 18.

2 Masia and Pienaar "Unravelling Safety Compliance in the Mining Industry: Examining the Role of Work Stress, Job Insecurity, Satisfaction and Commitment as Antecedents" 201137 SA Journal of Industrial Psychology 17.

3 Sibanye-Stillwater mine plans to be the first fully automated mine in South Africa. Braham "Wits, Sibanye-Stillwater Join Hands to Take Mining Digital" 2018 The Journal of the Southern African Institute of Mining and Metallurgy i vii.

4 Le Roux "Automation and Employment: The Case of South Africa" 201810 African Journal of Science, Technology, Innovation and Development 507508.

5 Carbonero, Ernst and Weber "Robots Worldwide: The Impact of Automation on Employment and Trade" 2018 International Labour Office, October 2018 Working Paper 36 12.

6 Carbonero et al 2018 International Labour Office, October 2018 Working Paper 362.

7 For example, in the mining industry it could lead to workers no longer going underground. See Lynas and Horberry "Human Factor Issues With Automated Mining Equipment" 2011 11 The Ergonomics Open Journal 7478.

8 Antin "The South African Mining Sector: An Industry at a Crossroads" 2013 Economy Report South Africa 11; Gumede "The Socio-Economic Effects and/or Modernising of Hard Rock Mines in South Africa" 201821 South African Journal of Economic and Management Sciences 1 1; Masia and Pienaar 2011 SA Journal of Industrial Psychology 7; and Tshoose "Placing the Right to Occupational Health and Safety Within the Human Rights Framework: Trends and Challenges for South Africa" 201447 CILSA 276284.

9 Stats SA Quarterly Labour Force Survey: Quarter 1 (2020) 3.

10 Mashaba "Mining Companies Rake in Huge Profits While Communities Live in Poverty" https://www.iol.co.za/the-star/news/mining-companies-rake-in-huge-profits-whilecommunities-live-in-poverty-18853390 (accessed 2019-12-18).

11 ILO Global Commission on the Future of Work 10.

12 Heald Why Is Collective Bargaining Failing in South Africa?: A Reflection on How to Restore Social Dialogue in South Africa (2016) 40; Mine Health and Safety Act 29 of 1996; and Skills Development Act 97 of 1998.

13 Heald Why Is Collective Bargaining Failing in South Africa? 32. 
occupational health and safety measures to be in place; workplaces could be safer in 4IR, but workers are unfamiliar with the machinery, and this could pose a risk. ${ }^{14}$ Lastly, workers' skills need to be developed on a continuing basis because of the evolving nature of 4IR. Moreover, automation will increase the need for certain skills and decrease the need for others. ${ }^{15}$ For these reasons, there is a question as to the relevance and impact of 4IR on the labour law framework in the mining sector of South Africa. This article considers this question in detail.

\section{COLLECTIVE BARGAINING AND STRIKE ACTION}

\section{Current legal framework for collective bargaining and strike action in the mines}

The Constitution of the Republic of South Africa, 1996 (the Constitution) states that everyone has the right to fair labour practices. ${ }^{16}$ The Constitution also provides for the right to strike. ${ }^{17}$ The Labour Relations Act (LRA) ${ }^{18}$ was enacted to give effect to the above constitutional provisions. ${ }^{19}$

\section{Collective bargaining}

The LRA aims to promote orderly collective bargaining. ${ }^{20}$ Collective bargaining is the primary mechanism that employees and trade unions use to settle conflict about employment-related matters. ${ }^{21}$ However, there is poor communication between the role players, and employees do not receive proper feedback on the problems that they are facing. ${ }^{22}$ Employees feel that collective bargaining should meet their "human needs, alleviate poverty, ensure fair labour practices, and thereby contribute to a better life". ${ }^{23}$ However, these expectations are high and unrealistic and the failure to meet them leads to insecurity and mistrust. ${ }^{24}$

The LRA suggests that collective bargaining is a voluntary process undertaken by parties..$^{25}$ However, the system of voluntarism has failed. ${ }^{26}$

14 Baloyi "The Fourth Industrial Revolution Is a Serious Concern to Trade Unions and Humanity" https://www.voices360.com/community-development/the-forth-industrialrevolution-is-aserious-concern-to-trade-unions-and-humanity-17051399 (accessed 201907-16).

15 Le Roux 2018 African Journal of Science, Technology, Innovation and Development 509.

16 S 23 (1) of the Constitution. This includes the right to form and join a trade union and to participate in trade union activities.

17 S 23(2) (c) of the Constitution.

1866 of 1996.

s 23(6) of the Constitution and s 1(a) of 66 of 1996.

s $1(d)$ of 66 of 1996.

Van Niekerk, Smit, Christianson, McGregor, and Van Eck Law@Work 3ed (2015) 388.

22 Twala "The Marikana Massacre: A Historical Overview of the Labour Unrest in the Mining Sector in South Africa" 20121 Southern African Peace and Security Studies 6163

23 Heald Why Is Collective Bargaining Failing in South Africa? 13.

24 Heald Why Is Collective Bargaining Failing in South Africa? 12 and 13.

25 South African National Defence Union v Minister of Defence (2007) 28 ILJ 1909 (CC) 41. 
There are multiple reasons why it has failed: employers stay the process, threaten to collapse it, or exploit the conditions of workers; employers use tactics to affect the effectiveness of the bargaining council agreement; and a large number of workers are left out of the agreements. ${ }^{27}$

The LRA contains organisational rights that are important because they "strengthen[...] and support[...] trade unions, and in doing so promote[...] the institution of collective bargaining". ${ }^{28}$ Organisational rights can be regulated in terms of a collective agreement. ${ }^{29}$ According to Theron, Godfrey and Fergus, the "[l]imited organisational rights dispensation provided by the LRA has not achieved the right balance between labour relations stability and workplace democracy". ${ }^{30}$ This leads to minority unions not having as much workplace coverage as a majority union, which creates problems, such as union rivalry and violence. ${ }^{31}$

Section 23(1)(d) of the LRA gives effect to the principle of majoritarianism in terms of which employees who are not members of a registered trade union can be bound to a collective agreement if a majority of the employees in the workplace are members of the trade union. ${ }^{32}$ The goal of this provision is to ensure that collective bargaining is orderly and productive..$^{33}$

Collective agreements are the end result in successful collective bargaining. In the AMCU $v$ Royal Bafokeng case, it is stated that, "[t]he voluntary nature of our labour relations system is held together by collective agreements". ${ }^{34}$ In order for an agreement to be valid, it must be in writing. ${ }^{35}$ It binds the parties to the collective agreement, "members of every other party to the collective agreement", as well as the members of the trade union and members of the employers' organisation who "are party to the collective agreement" if it deals with terms and conditions of employment or the conduct of employers towards employees or vice versa. ${ }^{36}$ It can bind nonmembers of the trade union if they were identified in the agreement, ${ }^{37}$ if "the agreement expressly binds the employees" 38 and if the trade union has the majority of employees as members. ${ }^{39}$

26 Coleman "Towards New Collective Bargaining, Wage and Social Protection Strategies in South Africa: Learning from the Brazilian Experience" 2013 Global Labour University Working Paper 176.

27 Ibid.

28 Van Niekerk et al Law@Work65.

29 S 20 of 66 of 1996

30 Theron, Godfrey and Fergus "Organisational and Collective Bargaining Rights Through the Lens of Marikana" 2015 ILJ 849849

31 As was seen in Marikana on 16 August 2012; see Theron et al 2015 ILJ 866.

$32 \mathrm{~S} 23(1)(d)$ of 66 of 1996.

33 Association of Mineworkers and Construction Union (AMCU) v Royal Bafokeng Platinum Limited 2018 ZALCJHB 208 (LAC) 19; Association of Mineworkers and Construction Union $(A M C U) v$ Chamber of Mines of South Africa 20176 BCLR 700 (CC) 44.

$34 \quad A M C U$ v Royal Bafokeng supra 26.

35 Diamond v Daimler Chrysler SA (Pty) Ltd 200627 ILJ 2595 (LC) par 26.

$36 \mathrm{~S} 23(1)$ of 66 of 1996.

S 23(1)(d)(i) of 66 of 1996 .

$S 23(1)(d)$ (ii) of 66 of 1996.

S 23(1)(d)(iii) of 66 of 1996. 
Minority unions do not always agree with the provisions set out in a collective agreement. This situation creates union rivalry and leads to problems in the collective bargaining process. Additionally, all employees are not afforded a fair say in changes brought about by a collective agreement. Many court cases have challenged the principle of majoritarianism, especially where minority unions and non-members are not consulted. 40

South Africa's collective bargaining has been called "bad faith bargaining" by some authors; trade unions propose extreme demands and refuse to compromise. ${ }^{41}$ This unwillingness to compromise increases the chances of a lengthy strike. ${ }^{42}$ Trade unions have been ineffective in dealing with workplace issues. ${ }^{43}$ Additionally, all parties' fears and concerns are not fully represented during the process. ${ }^{44}$ Collective bargaining in South Africa does not work because it is being used to solve problems it was not designed to address ${ }^{45}$ - for example, service delivery problems. Lastly, collective bargaining does not look at the root cause of the problems, such as the highly volatile political situation in South Africa. ${ }^{46}$

\section{Strike action}

Central to the concept of collective bargaining is the right to strike, ${ }^{47}$ which is used to maintain a balance between labour and capital. ${ }^{48}$ However, violence becomes an element in the strike if an employer hires replacement labour and attempts to continue operations while the workers are striking. ${ }^{49}$ This right is not absolute and is limited in terms of the Constitution. ${ }^{50}$ Additionally, it is limited procedurally and substantively by provisions in the LRA. ${ }^{51}$ In South Africa, strikes go on for long periods. ${ }^{52}$ Strikes no longer need majority

40 Lanxess Chrome Mining (Pty) Ltd v National Union of Mine Workers 2018 ZALCJHB 410 (LC); Transnet SOC Ltd 2018 ZALCJHB 131 (LC); AMCU v Royal Bafokeng supra 208 and $A M C U$ v Chamber of Mines supra 44. In AMCU v Royal Bafokeng supra the minority union, Association of Mineworkers and Construction Union, challenged the constitutionality of $s$ 23(1)(d) of the LRA. The court held that the principle was constitutional and leads to orderly collective bargaining. It held further that minority unions do not need to be consulted. See $A M C U$ v Royal Bafokeng supra par 11 and 19.

41 Botha and Lephoto "An Employer's Recourse to Lock-Out and Replacement Labour: An Evaluation of Recent Case Law" 201720 PELJ 123.

42 Botha and Lephoto 2017 PELJ 23.

43 Twala 2012 Southern African Peace and Security Studies 63.

44 Heald Why Is Collective Bargaining Failing in South Africa? 13.

45 Ibid.

46 Heald Why Is Collective Bargaining Failing in South Africa? 42

$47 \mathrm{~S} 23$ of the Constitution and $\mathrm{s} 1$ of the LRA.

48 Van Niekerk et al Law@Work 415 and Botha "Responsible Unionism During Collective Bargaining and Industrial Action: Are We Ready Yet?" 201548 De Jure 328332.

49 Botha and Lephoto 2017 PELJ 24 and s 76 of 66 of 1996.

50 Van Niekerk et al Law@Work 415.

51 Ibid.

52 The longest recorded strike occurred in Lonmin, Implats and Amplats in 2014. See Heald Why Is Collective Bargaining Failing in South Africa? 46; Rycroft "Strikes and the Amendments to the LRA" 2015 ILJ 1 3; Theron et al 2015 ILJ 866. 
support in order to be successful. ${ }^{53}$ Lengthy strikes impact employees' wages since they are not paid during the strike. ${ }^{54}$

There has been an increase in violent strike action ${ }^{55}$ to such an extent that the occurrence has been normalised. ${ }^{56}$ Violent acts are aimed at both people and property. ${ }^{57}$ Strike action is counterproductive and costly for employers because of the "damage to property, the expense of hiring private security firms, and the costs involved in litigation". 58 The current rise in violent strikes places the employer under a form of economic duress because employers are forced to give in to the demands of the workers. ${ }^{59}$ Ngcukaitobi is of the view that recent strike action is political and economic in nature and is transformed into a labour-related issue. ${ }^{60} \mathrm{It}$ has been stated that strike action is fuelled by "service delivery protests, vigilante action, xenophobic violence, Zama mining operations, taxi violence and other forms of community-based conflict in South Africa". ${ }^{61}$ The current rise in unprotected strikes in South Africa is an indication that the collective bargaining system is not working effectively. ${ }^{62}$

\section{Impact and relevance of the Fourth Industrial Revolution on collective bargaining and strike action in the mines}

The current way collective bargaining is conducted in South Africa will be challenged by $4 \mathrm{IR} .{ }^{63}$ There is a greater need for an effective collective bargaining system to be in place during the transition into 4IR. ${ }^{64}$ Collective

53 As is evident from the Lonmin strike in 2014 where a minority group of employees went on a strike that had an adverse effect on the mine. See Rycroft 2015 ILJ 2.

54 Du Plessis "Unions Should Think Twice About Strikes Before Committing Members to Hardship" https://www.miningmx.com/opinion/metal-heads/36615-unions-should-thinktwice-aboutstrikes-before-committing-members-to-hardship/ (accessed 2019-08-27). The recent strike at Sibanye-Stillwater that lasted a few days short of five months left striking workers with a loss of income of R56 400 per worker. See Malope "How Amcu's Joseph Mathunjwa 'Won' a Lost War" https://city-press.news24.com/Business/how-amcusjoseph-mathunjwa-won-a-lost-war20190421 (27-08-2019).

55 Benjamin "Beyond Dispute Resolution: The Evolving Role of the Commission for Conciliation, Mediation \& Arbitration" 2014 ILJ 10 as cited in Botha 2015 De Jure 344.

56 Botha 2015 De Jure 344. A survey conducted in 2013 by the Congress of South African Trade Unions showed that 60 per cent of workers felt that violence needed to be used in a strike. See Chinguno "Marikana: Fragmentation, Precariousness, Strike Violence and Solidarity" 402013 Review of African Political Economy 639639.

57 Rycroft 2015 ILJ 3.

58 Botha 2015 De Jure 344

59 Botha and Germishuys "The Promotion of Orderly Collective Bargaining and Effective Dispute Resolution, The Dynamic Labour Market and the Powers of the Labour Court (2)" 2017 THRHR 531531.

60 Ngcukaitobi "Strike Law, Structural Violence and Inequality in the Platinum Hills of Marikana" 2013 ILJ 836840.

61 Heald Why Is Collective Bargaining Failing in South Africa? 53.

62 Botha 2015 De Jure 342.

63 Heald Why Is Collective Bargaining Failing in South Africa? 29.

64 A study done in Spain showed that collective bargaining should be used to "ensure a fair transition towards a new world of work". It should improve flexibility and promote 
bargaining should be involved in employment creation as it offers a means for all role players to discuss ways to find solutions to problems associated with 4IR. ${ }^{65}$ It is proposed that the collective bargaining system become a compulsory system in terms of which there is a duty to bargain, especially in circumstances where 4IR negatively affects employees. The concept of "collective" in the bargaining process may no longer be relevant as a result of the focus on the individual and this can create a demand for individual bargaining that will require new legislation.

In general, collective agreements should focus on 4IR and entertain proposals as to future actions in expectation of the changes taking place in the workplace. ${ }^{66}$ The approach to negotiation needs to be revisited and feelings of trust and respect need to be incorporated to satisfy human needs. ${ }^{67}$

Social dialogue should include academia as well as the general public. 68 Academic theoretical understanding can provide solutions to problems, as it should provide an impartial assessment of the issues. The general public may gain an understanding of workers' feelings and the impact of 4IR on the community. There is a need to include workers directly in social dialogue ${ }^{69}$ through workplace fora. This will give "workers greater ownership to policies and solutions implemented; and it leads to more socially robust and innovative results". 70

Collective bargaining and negotiations increasingly use multimedia platforms ${ }^{71}$ a trend that can obviate mass meetings. ${ }^{72}$ This development can make the process easier as it is electronic and can enable communication between multiple parties in different locations - for example, via Skype. ${ }^{73}$ Emotion plays less of a role in negotiations and the negotiator has an accurate record of the negotiation..$^{74}$ It saves costs on hiring and travelling to a venue for negotiating. ${ }^{75}$ It makes it possible to conduct ballots relating to mandates and representivity via SMS and email, which is more reliable and accurate $^{76}$ than paper ballots. The increasing use of multimedia can involve a larger audience. ${ }^{77}$ Trade unions may be able to influence action at more than one mine and even across borders. ${ }^{78}$

employment creation (International Labour Office Synthesis Report of the National Dialogues on the Future of Work (2017) 62).

65

International Labour Office Synthesis Report 62.

International Labour Office Synthesis Report 63.

Heald Why Is Collective Bargaining Failing in South Africa? 118.

International Labour Organisation A Reflection on the Future of Work and Society (2017) 9.

International Labour Organisation A Reflection on the Future of Work and Society 14.

Ibid.

Heald Why Is Collective Bargaining Failing in South Africa? 40.

Heald Why Is Collective Bargaining Failing in South Africa? 31.

Ibid.

Ibid.

Ibid.

Ibid.

lbid.

78 International Labour Organisation Global Commission on the Future of Work 42; Heald Why Is Collective Bargaining Failing in South Africa? 31. 
The role of trade unions could diminish because there will be fewer employees working in the sector, and not as many permanent employees or employees on the premises. The role of the trade union will have to be revised and might need legislative protection to provide for compulsory representation. For trade unions to be relevant in $4 \mathrm{IR}$, they will need to anticipate and adapt to change in relation to the economy and the labour market. ${ }^{79}$ Self-maintaining technology and materials are being created that will replace labour and lead to fewer people in the workplace and fewer members of a trade union, resulting in their disappearance. ${ }^{80}$ It will be difficult for trade unions to represent individual employees as 4IR brings about a change from "collective" to "individual" in the workplace. ${ }^{81}$ It is suggested that an electronic applications platform will enable effective participation by a trade union but will make the need for collective bargaining practice superfluous. ${ }^{82}$

A mining company should hold lengthy discussions with all key role players on potential health and safety hazards that may result from a new system being considered. ${ }^{83}$ Collective bargaining can have a positive impact on health and safety issues if negotiations are carried out according to the provisions of the LRA and for the right reasons. ${ }^{84} \mathrm{~A}$ mining company should embark on applying a decision once all views are taken into account. ${ }^{85}$

Strike action has a potential to increase owing to a lack of communication and could lead to job losses in the mining sector, as employers are able to dismiss employees based on operational requirements. Employers will opt for automation rather than use replacement labour as they do currently.

\section{OCCUPATIONAL HEALTH AND SAFETY}

Occupational health and safety is especially critical in the mining sector owing to the harsh conditions that mineworkers face underground and on the surface. ${ }^{86}$ The Department of Labour has stated it is a sector with a high risk of workplace fatalities. ${ }^{87}$ However, the number of fatalities dropped in 2019 to 35 from 81 in 2018.88

79 Brown "Robots, New Technology, and Industry 4.0 in Changing Workplaces: Impacts on Labor and Employment Laws" 201825 American University Business Law Review 349362.

80 Heald Why Is Collective Bargaining Failing in South Africa? 40.

81 Heald Why Is Collective Bargaining Failing in South Africa? 43.

82 Heald Why Is Collective Bargaining Failing in South Africa? 43.

83 Badri, Boudreau-Trudel and Souissi "Occupational Health and Safety in the Industry 4.0 Era: A Cause for Major Concern?" 2018109 Safety Science 403 406; Chia, Ming Lim, Sng and Hwang "Need for a New Workplace Safety and Health (WSH) Strategy for the Fourth Industrial Revolution" 201962 American Journal of Industrial Medicine 275277.

84 Chia et al 2019 American Journal of Industrial Medicine 278.

85 Badri et al 2018 Safety Science 406.

86 Sieberhagen, Rothmann and Pienaar "Employee Health and Wellness in South Africa: The Role of Legislation and Management Standards" 20097 SA Journal of Human Resource Management 1818.

87 Ibid.

88 Kotze "35: SA on Track for Lowest Number of Fatalities in History" https://miningreview.com /southern-africa/35-sa-on-track-for-lowest-number-of-fatalities-in-recorded-history/ (accessed 2019-12-18). 
Because of the danger, more stringent regulation is required to help the health and safety record of mineworkers. ${ }^{89}$ Mineworkers contract numerous diseases while working, including tuberculosis (TB), human immunodeficiency virus (HIV), acquired immunodeficiency syndrome (AIDS) 90 and pulmonary silicosis. ${ }^{91}$ The effect of these diseases does not appear immediately but takes a number of months or years to show. ${ }^{92}$

\section{Current legal framework for occupational health and safety in the mines}

Everyone has a right to an environment that is not harmful to his or her health or well-being. ${ }^{93}$ Occupational health and safety in the mines is covered by the Mine Health and Safety Act (MHSA). ${ }^{94}$ Compensation for occupational diseases and injuries is provided for in the Compensation for Occupational Injuries and Diseases Act (COIDA) ${ }^{95}$ and the Occupational Diseases in Mines and Works Act (ODMWA); 96 ODMWA applies exclusively to the mining sector.

\section{Mine Health and Safety Act 29 of 1996}

The MHSA was enacted to protect the health and safety of mineworkers. ${ }^{97}$ According to the purpose of MHSA "[t]he [MHSA] is a statute specifically promulgated to provide for the protection of the health and safety of employees and other persons at mines". 98

The employer is responsible for ensuring that the mines are safe. ${ }^{99}$ The mine must be designed, constructed, equipped and in a condition to operate safely and the employer must enable a healthy working environment. ${ }^{100}$ The employer must provide for health and safety equipment and health and safety facilities that are serviceable and hygienic. ${ }^{101}$

The conditions faced by mineworkers, specifically women, do not appear to meet the standards that are mentioned in the MHSA. Tshoose states, " $99.8 \%$ of female workers are exposed to unhygienic conditions and lack of

8929 of 1996.

90 Hermanus "Occupational Health and Safety in Mining: Status, New Developments, and Concerns" 2007107 The Journal of Southern African Institute of Mining and Metallurgy 531 535.

91 Donoghue "Occupational Health Hazards in Mining: An Overview" 200454 Occupational Medicine 283284.

92 Nelson "Occupational Respiratory Diseases in the South African Mining Sector" 2013 Global Health Action 8990

$93 \mathrm{~S} 24($ a) of the Constitution.

9429 of 1996.

95130 of 1993

9678 of 1973.

97 $\mathrm{S} 1(\mathrm{a})$ of 29 of 1996.

29 of 1996.

9 S 2 of 29 of 1996.

$100 \mathrm{~S} 2(1)(a)(\mathrm{i})$ of 29 of 1996.

$101 \mathrm{~S}$ 6(1)(a) and (b) of 29 of 1996. 
access to adequate sanitary facilities while working underground". ${ }^{102}$ Women are unhappy with the type and style of the personal protective equipment that is available. ${ }^{103}$

Employers must compile an annual health and safety report and it must include statistics on health and safety. ${ }^{104}$ Employers evidently disclose all health and safety risks that are present on the mines. For instance, Implats Platinum disclosed that carbon dioxide and sulphur dioxide levels were exceeded on the mines. ${ }^{105}$ The penalty for breaching occupational health and safety law in South Africa is set at a low level. ${ }^{106}$ The mining industry does not fully comply with all health and safety requirements. ${ }^{107}$ The failure to enforce the provisions of the MHSA may be linked to inspectorate authorities not having sufficient knowledge of how to deal with situations where the occupational health and safety legislation is violated. ${ }^{108}$ (Legislation contains provisions on non-compliance with occupational health and safety law, which include fines and imprisonment.) ${ }^{109}$

In terms of the MHSA, if the worker subjectively believes that the work is dangerous, he or she has the right to refuse the work. ${ }^{110}$ This is the only mechanism workers have to exercise control over their occupational health and safety. ${ }^{111}$ According to Hermanus, workers are unaware of how to inform their managers about risks they face. ${ }^{112}$

Risk management is important according to the MHSA. ${ }^{113}$ In practice, there is no consistency in the approach taken by employers. ${ }^{114}$ When risk management is dealt with, there appears to be a lack of training, which leads to a lack of improvement in occupational health and safety. ${ }^{115}$

102 Zungu "Occupational Health and Safety Challenges Reported by Women in Selected South African Gold and Platinum Mines" 2012 Occupational Health Southern Africa 6-13 as cited in Tshoose 2014 CILSA 284.

103 Zungu 2012 Occupational Health Southern Africa 6-13 as cited in Tshoose 2014 CILSA 284.

$104 \mathrm{~S} 2(1)(c)$ of 29 of 1996.

105 Howard "Half-Hearted Regulation: Corporate Social Responsibility in the Mining Industry" 2014131 SALJ 1124.

106 Loewenson "Globalization and Occupational Health: A Perspective From Southern Africa" 2001 79(9) Bulletin of the World Health Organization 865-866 as cited in Tshoose 2014 CILSA 285.

107 Murray, Davies and Rees "Occupational Lung Disease in the South African Mining Industry: Research and Policy Implementation" 201132 Journal of Public Health Policy 6571.

108 Tshoose 2014 CILSA 289.

$109 \mathrm{~S} 55 \mathrm{~A}$ of 29 of 1996.

$110 \mathrm{~S} 23(1)(a)$ of 29 of 1996.

111 Coulson, Stewart and Saeed 'South African Mineworkers' Perspectives on the Right to Refuse Dangerous Work and the Constraints to Workers Self-Regulation" 2019119 Journal of Southern African Institute of Mining and Metallurgy 2128.

112 Hermanus 2007 The Journal of Southern African Institute of Mining and Metallurgy 536.

113 lbid.

114 Hermanus 2007 The Journal of Southern African Institute of Mining and Metallurgy 537.

115 Hermanus 2007 The Journal of Southern African Institute of Mining and Metallurgy 531. 


\section{Occupational Diseases in Mines and Works Act 78 of 1973}

ODMWA provides for the payment of compensation for diseases that were contracted by an employee while working in a mine. ${ }^{116}$ A Mines and Works Compensation Fund has been established. ${ }^{117}$ If a person dies after a fixed date, then the amount due to him or her is payable to dependants whom the commissioner designates. ${ }^{118}$ The amount payable includes the value of food or quarters provided by the owner, overtime pay or special remuneration that was performed for ordinary work. However, it excludes the following payments: intermittent overtime, non-recurrent occasional services, cost to cover special expenses, and ex gratia payments. ${ }^{119}$ Compensation is calculated in terms of an employee's past remuneration and does not take inflation into account. ${ }^{120}$ It does not take into account all the costs involved in being injured or contracting a disease. ${ }^{121}$ For instance, an employee cannot claim for pain, suffering and loss of the amenities of life when he or she claims damages. ${ }^{122}$ Future loss of earnings is also not taken into account when compensation is awarded. Thus, "workers and their dependants are systematically impoverished". ${ }^{123}$

There is a dispute over compensation provided in terms of ODMWA. ODMWA provides for lump sum payments to an employee or his or dependants ${ }^{124}$ but periodic payments would be more beneficial because lump sum payments tend to cover the current obligations of the employee or the dependants. There has not been an implementation of government policy to improve compensation for miners and bring it into line with compensation given to workers not from the mining sector. ${ }^{125}$

A further difficulty ODMWA poses is that it makes little provision for an employee's reintegration ${ }^{126}$ - for instance, it places the responsibility on government to provide occupational health services. ${ }^{127}$ Where an employee is temporarily disabled, the LRA provides that an employer must defer a dismissal. ${ }^{128}$ ODMWA does not promote preventive measures even though they are cost effective. ${ }^{129}$

Aim of ODMWA.

S 61(1) of 78 of 1973

$11 \mathrm{~S} 80(4)$ of 78 of 1973 read with subsection (3), which provides that this amount should be at least R34 458.

$119 \mathrm{~S} 80 \mathrm{~A}(1)$ of 78 of 1973.

120 Olivier, Smit and Kalula Social Security: A Legal Analysis (2003) 485.

21 Olivier et al Social Security 485.

122 Olivier et al Social Security 480.

123 Ibid.

$124 \mathrm{~S} 81$ of 78 of 1973.

125 Murray et al 2011 Journal of Public Health Policy 70.

126 Olivier et al Social Security 493.

27 Olivier et al Social Security 493 fn 300.

28 Olivier et al Social Security 491.

129 Olivier et al Social Security 493. 
Occupational diseases become evident only after a while. ${ }^{130}$ This factor is problematic for migrant workers on the mines in South Africa because they may return to their home country before showing signs of disease. ${ }^{131}$ Migrant employees do not have a mechanism at home to claim compensation from either ODMWA or COIDA. ${ }^{132}$ In addition, "[t]he functioning of the compensation system in rural areas is insufficient". ${ }^{133}$

In 2016, the High Court passed judgment in a class action that was instituted by 68 mineworkers against various mining companies. ${ }^{134}$ The mineworkers had contracted silicosis and TB while working in the mines ${ }^{135}$ and the action included all workers who worked in a gold mine after 12 March 1965. ${ }^{136}$ In 2019, the High Court made the settlement agreement an order of court. ${ }^{137}$ The settlement amounts to R5 billion, to be paid to a trust and paid out to past and current mineworkers or their dependants if they contracted silicosis and TB as a result of working in the gold mines. ${ }^{138}$ This is a landmark case, and will compensate workers and their dependants who do not claim under ODMWA.

\section{Compensation for Occupational Injuries and Diseases Act 130 of 1993}

COIDA is relevant to the mining sector despite it having its own piece of legislation, as is evident from section 25 of COIDA. ${ }^{139}$ The provisions apply to casual and to full-time employees. ${ }^{140}$ COIDA provides for the establishment of a compensation fund. ${ }^{141}$

COIDA provides an extensive list of diseases that are considered as compensatable. However, if an employee contracts a disease not listed in COIDA, then the employee needs to prove that the disease was contracted in the workplace and that it arose in the course of his or her employment. ${ }^{142}$ It may be difficult for an employee to prove that a disease arose in the workplace because not many employees have access to medical facilities or a specialist to undergo the necessary tests to prove their allegation. ${ }^{143}$ All of

130 Olivier et al Social Security 477.

131 lbid.

132 Ibid.

133 Olivier et al Social Security 474.

134 Nkala v Harmony Gold Mining Company Limited 20167 BCLR 881 (GJ).

135 Nkala v Harmony Gold Mining Company Limited supra par 6.

136 Nkala v Harmony Gold Mining Company Limited supra par 40 (i) and 41.

137 Ex Parte Nkala and Others 2019 ZAGPJHC 260 par 127.

138 Ex Parte Nkala and Others supra 23.

139 S 25 of 130 of 1993 provides: "If an employee meets with an accident (b) while he is engaged in or about his employer's mine, works or premises in organized first aid, ambulance or rescue work, fire-fighting or any other emergency service; (c) ... such accident shall, for the purposes of this Act, be deemed to have arisen out of and in the course of his employment."

$140 \mathrm{~S} 1$ (xix) of 130 of 1993.

$141 \mathrm{~S} 15(1)$ of 130 of 1993 . "Compensation" is defined in s 1 of 130 of 1993 as "compensation in terms of this Act and, where applicable, medical aid or payment of the cost of such medical aid; (xl)".

$142 \mathrm{~S} 65(1)(b)$ of 130 of 1993.

143 Olivier et al Social Security 466. 
the above leads to employees not reporting diseases that are not mentioned in COIDA. ${ }^{144}$

An employee's compensation is calculated with reference to his or her earnings. ${ }^{145}$ An employee cannot claim for pain, suffering and loss of the amenities of life or the future loss of earnings. ${ }^{146}$ The employee's past earnings are considered and the calculation does not take inflation into account. ${ }^{147}$ As stated earlier, this leads to a situation where "workers and their dependants are systematically impoverished". ${ }^{148}$ As stated, many occupational diseases become evident only after a while and this can be problematic for migrant workers because disease may become evident only on their return to their home country. ${ }^{149}$ They cannot claim compensation under COIDA while they are outside South Africa. ${ }^{150}$ In rural areas, workers also face a problem because there is no compensation system. Family members and the community have to take care of the person.

COIDA fails to provide employees with an opportunity to be reintegrated into the workplace once they suffer from an injury or a disease. ${ }^{151}$ COIDA does not promote preventive measures even though they are cost effective. ${ }^{152}$

\section{Impact and relevance of the Fourth Industrial Revolution on occupational health and safety in mines}

The occupational health and safety of workers in 4IR, specifically when new machinery is introduced, is an important issue. ${ }^{153}$ There have been attempts to make the introduction of new machinery compliant with general occupational health and safety. ${ }^{154}$ However, as the process is more complex with $4 \mathrm{IR}$, this can be difficult because it can lead to greater occupational health and safety hazards. ${ }^{155}$ The risks cannot be predicted in the same manner as before..$^{156}$ It is suggested that new models of risk analysis need to

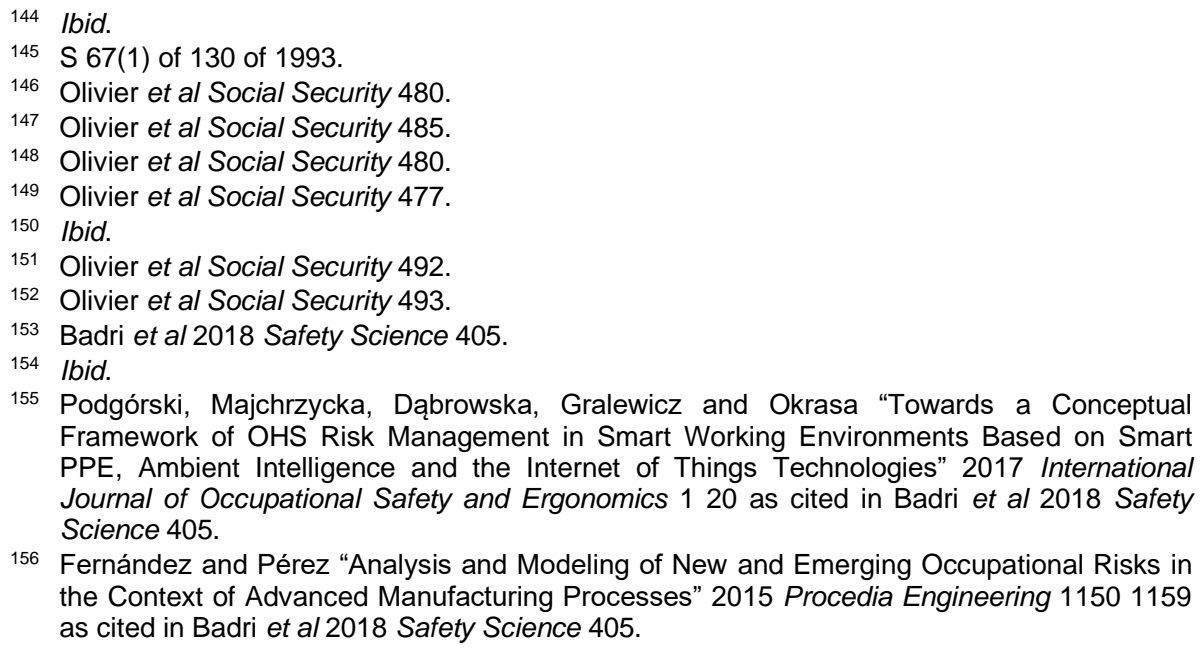

155 Podgórski, Majchrzycka, Dąbrowska, Gralewicz and Okrasa "Towards a Conceptual Framework of OHS Risk Management in Smart Working Environments Based on Smart PPE, Ambient Intelligence and the Internet of Things Technologies" 2017 International Journal of Occupational Safety and Ergonomics 120 as cited in Badri et al 2018 Safety Science 405.

156 Fernández and Pérez "Analysis and Modeling of New and Emerging Occupational Risks in the Context of Advanced Manufacturing Processes" 2015 Procedia Engineering 11501159 as cited in Badri et al 2018 Safety Science 405. 
be created to enable monitoring of all occupational health and safety hazards. ${ }^{157}$

Jones states that a new regulatory framework for occupational health and safety in 4IR will not come in time, as was the case in previous revolutions. ${ }^{158}$ Current legislation will be relevant and valid for the coming years because the laws are adaptable. ${ }^{159}$ It is suggested that standards should be looked at first, because if standards are not changed, it will have an adverse effect on occupational health and safety management. ${ }^{160}$ This will ensure that the new system complies with a standard and is safe to be placed in a mine. ${ }^{161}$ These standards need to be flexible and agile to be able to adapt to any further changes. ${ }^{162}$ It will be advisable for mining companies to have an in-house framework for occupational health and safety to ensure that risks can be detected timeously. ${ }^{163}$ It is suggested that relying only on occupational health and safety legislation in the workplace will not be effective. ${ }^{164}$

There is a need to embrace common values, such as "stewardship, common good, and human dignity among all stakeholders to ensure continued occupational safety and health". ${ }^{165}$ Key role players can develop these common values. ${ }^{166}$

As previously stated, risk management is an important component of the MHSA and will be highly important in 4IR. ${ }^{167}$ Mining companies have to be aware and able to prepare themselves for these risks. It will be important to have a system where data can be gathered from different places and be accessible to all involved in the mining sector - for example, on a database available via the Internet. ${ }^{168}$

Occupational health and safety management should be a focus area because it will lead to the effectiveness and efficiency of regulation. ${ }^{169}$ Workers should be involved in occupational health and safety

157 Badri et al 2018 Safety Science 405.

158 Jones "With the IEC/ISO 17305 Safety Standard Delay, What's Next? Rockwell Automation" http://www.rockwellautomation.com/en_NA/news/the-journal/detail.page?pagetitle=With-the -IEC\%2FISO-17305-Safety-Standard-Delay\%2CWhat\%E2\%80\%99s-Next\%3F\&content type=magazine \&docid=4b89588d842bf4d13ed1e631a1c9c26d (accessed 2017-07-18) as cited in Badri et al 2018 Safety Science 407.

159 Badri et al 2018 Safety Science 407.

160 Ibid.

161 Ibid.

162 Badri et al 2018 Safety Science 408.

163 Badri et al 2018 Safety Science 407.

164 Chia et al 2019 American Journal of Industrial Medicine 278.

165 World Economic Forum Values and the Fourth Industrial Revolution: Connecting the Dots Between Value, Values, Profit, and Purpose (14 November 2016) http://www3.weforum.org/docs/WEF_Values and the_Fourth_Industrial_Revolution_WHITEPAPER.pdf (accessed 2018-10-11) as cited in Chia et al 2019 American Journal of Industrial Medicine 279

166 Chia et al 2019 American Journal of Industrial Medicine 2017.

167 Badri et al 2018 Safety Science 408.

168 Ibid.

169 Bluff, Gunningham and Johnstone OHS Regulation for a Changing World of Work (2004) 43. 
management ${ }^{170}$ as their participation can make occupational health and safety management run effectively and efficiently. ${ }^{171}$

The world of work is changing and with it the way employer-employee relationships are carried out. "Full-time employment" might be an obsolete concept in the future as a result of an increase in the employment of independent as well as part-time workers. ${ }^{172}$ These changes can potentially exclude a large number of employees from the ambit of occupational health and safety legislation. ${ }^{173}$ Independent workers do not fall under the definition of "employee" in compensation legislation. ${ }^{174}$ Subcontractors and workers who are outsourced are under pressure owing to competition, which can lead to health and safety issues in the workplace. ${ }^{175}$

The impact of $4 \mathrm{IR}$ may be devastating for the mental health of workers because of the complexity of this revolution as well as the fear of being retrenched. ${ }^{176}$ The increasing complexity of 4IR can lead to workers experiencing psychosocial afflictions ${ }^{177}$ such as depression and anxiety. There is a trend towards a greater number of people suffering from psychosocial problems such as the syndrome of "burn-out"178 and musculoskeletal disorders. ${ }^{179}$ These issues are not recognised in legislation, especially occupational health and safety legislation. ${ }^{180}$ Employers need to develop better ways of dealing with mental health issues that are present in the workplace. ${ }^{181}$

Safety in the mines is jeopardised by skills shortages and aggravated by the high level of unemployment, leading to an increase in the number of illegal miners who contribute to worsening statistics by entering unsafe mine shafts. These acts have repercussions for the whole industry.

170 Bluff et al OHS Regulation for a Changing World of Work 45.

171 Gustaven "Improving the Work Environment: A Choice of Strategy" 1980 International Labour Review 271-286 as cited in Bluff et al OHS Regulation for a Changing World of Work 49.

172 Chia et al 2019 American Journal of Industrial Medicine 278. This scenario will arise in the case of machinery that does not need human intervention to work but needs a human to programme and maintain it from time to time (Lynas and Horberry 2011 The Ergonomics Open Journal 74).

173 Chia et al 2019 American Journal of Industrial Medicine 278.

174 S 1 (xix) of 130 of 1993.

175 Bluff et al OHS Regulation for a Changing World of Work 3.

176 Sirvio, Ek, Jokelainen, Koiranen, Järvikoski and Taanila "Precariousness and Discontinuous Work History in Association with Health" 2012 Scandinavian Journal of Public Health 360-367 as cited in Chia et al 2019 American Journal of Industrial Medicine 276.

177 Leka and Jain "Health Impact of Psychosocial Hazards at Work: An Overview" 2010 World Health Organization, Geneva 136 as cited in Badri et al 2018 Safety Science 407.

178 Bluff et al OHS Regulation for A Changing World of Work 48.

179 Bluff et al OHS Regulation for A Changing World of Work 2. It is found "that an injury serious enough to lead to at least a week off of work almost triples the combined risk of suicide and overdose death among women and increases the risk by 50 per cent among men" (author unknown "BU Finds Workplace Injuries Contribute to Rise in Suicide, Overdose Deaths" https://www.eurekalert.org/pub_releases/2019-07/buso-bfw072219.php (accessed 2019-08-26)).

180 Badri et al 2018 Safety Science 407.

181 Rinker "Employers Step Up Efforts to Help Workers Address Mental Health" https://abcnews.go.com/Health/employers-step-efforts-workers-address-mentalhealth/story?id=64483957 (accessed 2019-08-26). 


\section{SKILLS SHORTAGES AND SKILLS DEVELOPMENT}

Unemployment and skills shortages are major issues in South Africa; currently the official unemployment rate is 30,8 per cent. ${ }^{182}$ Automation will make many kinds of work obsolete. However, it will also lead to new jobs being created. ${ }^{183}$

\section{Current legal framework for skills development in the mines}

\section{Skills Development Act 97 of 1998 and Skills Development Levies Act 9 of 1999}

In South Africa, the Skills Development Act (SDA) regulates skills development in the workplace. ${ }^{184}$ Skills development in South Africa is funded in terms of the provisions of the Skills Development Levies Act (SDLA). ${ }^{185}$ The purpose of the SDA is to develop skills and improve the quality of the working life of employees. ${ }^{186}$ It aims to promote selfemployment and to increase investment in education and training. ${ }^{187}$ It promotes the use of the workplace as an active learning environment and aims to improve the employability of those that were previously disadvantaged by way of introducing training and education schemes. ${ }^{188}$

A Sectoral Education and Training Authority (SETA) plays an important role in the workplace because it uses hands-on methods to promote and develop skills development. The Minister of Higher Education and Training may establish a SETA for any national economic sector for a specific time by way of notice in the Government Gazette. ${ }^{189}$

The SDA covers learnerships. A learnership must include a structured learning component and a structured work experience component in order for it to be established by a SETA; ${ }^{190}$ it needs to be registered with the Director-General and it needs to lead to a qualification registered by the South African Qualifications Authority. ${ }^{191}$

The SDA provides for skills programmes that are funded by SETAs. ${ }^{192}$ A programme may be funded by a SETA or by the Director-General. ${ }^{193}$ To

\footnotetext{
182 Stats SA "Quarterly Labour Force Survey (QLFS): Q3:2020" http://www.statssa.gov.za/?p=13765 (accessed 2020-12-10).

183 ILO Global Commission on the Future of Work 18.

$184 \mathrm{~S} 2$ of 97 of 1998.

185 Preamble of 9 of 1999.

$186 \mathrm{~S} 2(1)(a)(\mathrm{i})$ of 97 of 1998.

$187 \mathrm{~S} 2(1)(a)$ (iii) and (b) of 97 of 1998.

$188 \mathrm{~S} 2(1)(c)-(f)$ of 97 of 1998

$189 \mathrm{~S} 9(1)(a)$ of 97 of 1998.

$190 \mathrm{~S}$ 16(a) and (b) of 97 of 1998.

$191 S$ 16(c) and $(d)$ of 97 of 1998.

192 S 20(3) of 97 of 1998. A "skills programme" as defined in s 20(1) of 97 of 1998 means a programme that: "(a) is occupationally based; (b) when completed, will constitute a credit
} 
qualify for funding, it must be developed according to "(i) the sector skills development plan of the SETA; or (ii) the national skills development strategy" and funds must be available. ${ }^{194}$

The government has focused on skills shortages but this issue is still a major concern. ${ }^{195}$ There have been numerous changes to the educational system but they fail to reach the desired end - namely, the development of necessary skills. ${ }^{196}$ The government has tried to settle the issue through an education budget that funds the development of necessary skills, but despite its efforts, there are structural issues that hinder its progress, such as not having the correct resources and facilities. ${ }^{197}$

\section{Mineral and Petroleum Resources Development Act 28 of 2002}

The aim of the Mineral and Petroleum Resources Development Act (MPRDA) is to provide access to, and sustain the development of, the mineral and petroleum resources of South Africa and all other related matters. ${ }^{198}$

All mineral rights vest in the State and the State can grant such rights to a person provided that certain requirements are met. ${ }^{199}$ An application for a mining right must be lodged with the Minister of Minerals and Energy. ${ }^{200}$ An application for a mining right must have a social and labour plan attached.201

The regulations of the MPRDA make provision for social and labour plans with which the holder of a mining right must comply. ${ }^{202}$ The objectives of the social and labour plan are to promote employment and advance social and economic welfare, "contribute to the transformation of the mining industry"

towards a qualification registered in terms of the National Qualifications Framework contemplated in Chapter 2 of the NQF Act; (c) uses training providers referred to in section $17(1)(c)$; and (d) complies with any requirements that may be prescribed." See also $s$ 20(3)(a) of 97 pf 1998.

$193 \mathrm{~S} 20(3)(a)$ of 97 of 1998.

194 Ss $20(3)(b)$ and $(c)$ of 97 of 1998.

195 Rasool and Botha "The Nature, Extent and Effect of Skills Shortages on Skills Migration in South Africa" 20119 SA Journal of Human Resource Management 11.

196 Ibid.

197 Rasool and Botha 2011 SA Journal of Human Resource Management 3. Harmony Gold Mine provided 96 per cent of its workers with training in 2015. The training and development programmes included "skills development, adult education and training, a bridging school, learnerships, bursaries, graduate development, talent management and supervisory and leadership development". AngloGold Ashanti is also involved in skills development, which it offers its workers as well as the community where the mine is situated. It offers bursaries, learnerships, internships, work exposure, vacation programmes and graduate training. The bursaries are targeted at mining specialists (Melass "In Training" https://www.miningdecisions.com/sustainability/in-training/ (accessed 2019-10-03)).

198 Preamble of 28 of 2002.

199 Centre for Applied Legal Studies (CALS): The Social Labour Plan Series 2016 Phase 1: System Design Trends Analysis Report 14.

$200 \mathrm{~S} 22(1)$ and (1)(a) of 28 of 2002.

201 Regulation 42(1)(a) of 28 of 2002 and Department of Mineral Resources Guidelines for the Submission of a Social and Labour Plan (2010) 4

$202 \mathrm{~S} 25(2)(f)$ of 28 of 2002. 
and "ensure that holders of mining rights contribute towards the socioeconomic development of the areas in which they are operating". ${ }^{203}$

Mining companies have "to develop and implement comprehensive Human Resources Development Programmes", among other plans. ${ }^{204}$ The human resource development programme's primary objective "is to ensure development of requisite skills in respect of learnerships, bursaries (of core and critical skills), artisans, ABET training and other training initiatives reflective of demographics". 205 The skills that need to be provided to mineworkers are not limited to skills needed to work on the mines but also skills that can be used once the mine has closed. ${ }^{206}$ The skills development plan needs to comply with skills development legislation. ${ }^{207}$

This ensures that the mining company includes the sustainability of the community in its plan for the duration of the mine's operation. ${ }^{208}$ The plan is drafted in consultation with the mining community. ${ }^{209}$ An annual report showing compliance with the social and labour plan must be submitted to the Director-General by the holder of the mining right $^{210}$ and to the regional manager or designated agency. ${ }^{211}$ The social and labour plan is binding on the mining company that holds the mining right, and if there is noncompliance, the mining right can be suspended. ${ }^{212}$

Leon is of the view that social and labour plans are unworkable and do not provide guidance on how to reach the outcomes mentioned in the social and labour plan. ${ }^{213}$ The lack of guidance on these issues can make it difficult for mining companies to comply and leads to the plan not being carried out fully. The plan is viewed as a mere means to get a mining licence and is not completed to benefit the mining community. ${ }^{214}$

Many social and labour plans are vague on how a community can hold a mining company accountable for what is provided in the social and labour plan. ${ }^{215}$ Some community members wish to engage with the other role players but lack the expertise to engage in the discussions owing to the technical nature of mining. ${ }^{216}$ Language is also a barrier in these communities because not all members speak fluent English. ${ }^{217}$ Mining

203 Regulation 41 of 28 of 2002.

204 Department of Mineral Resources Guidelines for a Social and Labour Plan 4.

205 Department of Mineral Resources Guidelines for a Social and Labour Plan 8.

206 Rogerson "Mining Enterprise, Regulatory Frameworks and Local Economic Development in South Africa" 20115 African Journal of Business Management 1337313375.

207 Department of Mineral Resources Guidelines for a Social and Labour Plan 8.

208 Regulation 41 of 28 of 2002.

209 Meyersfeld "Empty Promises and the Myth of Mining: Does Mining Lead to Pro-Poor Development?" 20172 Business and Human Rights Journal 3139.

210 Department of Mineral Resources Guidelines for a Social and Labour Plan 6.

211 Rogerson 2011 African Journal of Business Management 13375.

212 S 93 of 28 of 2002.

213 Leon "Marikana, Mangaung and the Future of the South African Mining Industry" 2013 Journal of Energy and Mineral Resources Law 171186.

214 Leon 2013 Journal of Energy and Mineral Resources Law 186.

215 Lamola A Critical Analysis of the Enforceability of Social and Labour Plans in the South African Mining Industry (master's dissertation, University of Pretoria) 201736.

216 Howard 2014 SALJ 20.

217 Ibid. 
companies face certain consequences if they do not comply with their social and labour plans - for instance, a mining company's licence may be withdrawn or revoked by the Minister of Mineral Resources. ${ }^{218}$ However, this sanction is rarely invoked. Moreover, without guidelines on the level or target that needs to be fulfilled, only a complete failure to comply is regarded as non-compliance. ${ }^{219}$

\section{The impact and relevance of the Fourth Industrial Revolution on skills shortages and skills development in the mines}

In South Africa, research has begun on $4 I R$ and its impact on the workforce, ${ }^{220}$ but there are no processes in place to "ensure employment creation in the digital age". ${ }^{221}$ According to Heald, "[n]ew skills, trades, jobs, professions and careers will need to be designed from scratch". ${ }^{222}$ It will be necessary to ensure that income earned from flexible employment is predictable so as to create employment security. ${ }^{223}$

A lack of skills leads to productivity problems, ${ }^{224}$ which will be more apparent in 4IR where new skills will be necessary to perform certain tasks; without the availability of these skills, the mines will not be able to run efficiently. Jobs that are repetitive and are predictable will be carried out by robots. 225 Technical skills could become redundant in the mining sector because most tasks require such skills. 226 The World Economic Forum identifies the skills challenges as "skills mismatches and skills redundancy". 227

218 Lamola A Critical Analysis 40.

219 Lamola A Critical Analysis 41.

220 Campbell "Fourth Industrial Revolution Centre Launched in South Africa" https://www.engineeringnews.co.za/article/fourth-industrial-revolution-centre-launchedinsouth-africa-2019-04-16/rep_id:4136 (accessed 2019-07-15); Gavaza "Fourth Industrial Revolution Summit Opens in Midrand" https://www.businesslive.co.za/bd/national/2019-0705-fourth-industrial-revolution-summitopens-in-midrand/ (accessed 2019-07-15); Author unknown "President Cyril Ramaphosa Highlights the Fourth Industrial Revolution in SA" https://albertonrecord.co.za/217169/president-cyril-ramaphosa-highlights-fourthindustrialrevolution-sa/ (accessed 2019-07-15); Shapshak "South Africa Prepares for 4IR and 'More Entrepreneurial' Govt" https://www.forbes.com/sites/tobyshapshak/ 2019/07/12/south-africa-prepares-for-4ir-andmore-entrepreneurial-govt/\#6f01746c38cd (accessed 2019-07-15).

221 Heald Why Is Collective Bargaining Failing in South Africa? 42.

222 Heald Why Is Collective Bargaining Failing in South Africa? 35.

223 Ibid.

224 Badri et al 2018 Safety Science 407.

225 Khoosal "Don't Panic, it's Just the Fourth Industrial Reshuffling" https://www.businesslive.co.za/bd/opinion/2019-05-29-dont-panic-its-just-thefourthindustrial-reshuffling/ (accessed 2019-08-27).

226 World Skills Conference 2019 Mission Talent-Mass Uniqueness: A Global Challenge for One Billion Workers (2019) 22.

227 World Skills Conference 2019 Mission Talent- Mass Uniqueness: A Global Challenge for One Billion Workers 18. A skills mismatch occurs if the present skill does not meet the skills needed. In South Africa, highly qualified individuals do jobs that require a lower qualification. Skills redundancy is when a person has skills that are no longer required - for 
Role players should predict what skills will be needed and develop programmes specifically to cover the development of such skills. ${ }^{228}$ It is necessary to implement teaching, learning and training in the latest technologies in order to equip the current and future workforce. ${ }^{229}$ The retraining of existing workers is necessary if unemployment levels are to be decreased.

The training has to be aimed at developing a combination of conventional task-associated expertise with computer skills. ${ }^{230}$ Trade unions can play a role in negotiating on the retraining of the current workforce. ${ }^{231}$ It is important that mineworkers have the skills needed to operate the new machinery; otherwise, there could be a negative impact on the safety of the mine and workers. If the transformation is not well managed, it has the potential to widen the skills gap. ${ }^{232}$

New skills are difficult to acquire for an ageing population and even more difficult for a workforce that lacks the necessary schooling to enlist in programmes to learn new skills; ${ }^{233}$ the mining sector consists mainly of unskilled or semi-skilled workers who have not finished school.

Job losses are a major challenge that is worsened by the current unemployment rate. ${ }^{234} \mathrm{Job}$ loss is likely to affect low-skilled workers, mostly from previously disadvantaged groups. ${ }^{235}$ The mining sector expects "to see a reduction in their workforce due to automation". 236

Research has shown that highly skilled and high-value employees are undergoing re-skilling and up-skilling, ${ }^{237}$ although it is the jobs of the lowskilled that are threatened by automation. Also, the up-skilling of low-skilled workers will lead to lifelong learning becoming a reality. ${ }^{238}$

instance, carrying out repetitive tasks (World Skills Conference 2019 Mission Talent-Mass Uniqueness: A Global Challenge for One Billion Workers 18 and 19).

228 Manda and Dhaou "Responding to the challenges and opportunities in the $4^{\text {th }}$ Industrial revolution in developing countries" 2019 Association for Computing Machinery 246.

229 Ncube "The Fight of Labour Unions for Relevance" https://www.news24.com/MyNews24/ the-fight-of-labour-unions-for-relevance-20190208 (accessed 2019-07-16).

230 Lorenz, Rüßmann, Strack, Lasse, Bolle "Man and Machine in Industry 4.0: How Will Technology Transform the Industrial Workforce Through 2025?" 2015 The Boston Consulting Group 22 and European Commission "Factories of the Future: Multi-Annual Roadmap for the Contractual PPP under Horizon 2020" European Factories of the Future Research Association (EFFRA) 136 as cited in Badri et al 2018 Safety Science 407.

231 Ncube https://www.news24.com/MyNews24/the-fight-of-labour-unions-for-relevance20190208.

232 World Economic Forum The Future of Jobs Report (2018) 17.

233 Lorenz et al 2015 The Boston Consulting Group 22 and European Commission European Factories of the Future Research Association (EFFRA) 136 as cited in Badri et al 2018 Safety Science 407.

234 Manda and Dhaou 2019 Association for Computing Machinery 247.

235 Manda and Dhaou 2019 Association for Computing Machinery 450.

236 World Economic Forum The Future of Jobs Report 17.

237 Bain and Company Labor 2030: The Collision of Demographics, Automation and Inequality (2018); McKinsey \& Company Skill Shift: Automation and the Future of the Workforce Discussion Paper, McKinsey Global Institute (2018); Barclays Robots at the Gate: Humans and Technology at Work (2018) as cited in World Economic Forum The Future of Jobs Report 14.

238 World Economic Forum The Future of Jobs Report 14. 
A highly skilled workforce is necessary for a country to be successful in $4 I R,{ }^{239}$ which presents a problem for South Africa. Statistics South Africa estimates that 30 per cent of workers in South Africa are unskilled, 46 per cent are semi-skilled and only 24 per cent are skilled. ${ }^{240}$ This situation needs to change; skilling and re-skilling needs to be made a priority. ${ }^{241} \mathrm{High}$ levels of unemployment and skills shortages lead to illegal mining, which is unsafe for the miners.

Even in the event that automation affects only specific tasks, many workers do not have the right skills to adapt to new technologies, thus negatively affecting wages as well as job quality. ${ }^{242}$ The workforce needs to be agile and equipped with futureproof skills. ${ }^{243}$

The World Economic Forum holds the view that humans will not be replaced but will be augmented by machines. ${ }^{244}$ In this process, automation enhances and complements human strength, enabling a worker to reach full potential and gain a competitive advantage and free workers from routine and repetitive tasks. ${ }^{245}$

Government, trade unions and companies need to cooperate in deciding on job creation. ${ }^{246}$ Businesses will need to partner with other role players in order to manage the "large-scale retraining and upskilling challenges ahead". ${ }^{247}$ Government is to incentivise lifelong learning by "ensuring shared standards for retraining". ${ }^{248}$ They need urgently to "address the problem of the future of employment". 249 Trade unions play a role in the development of the social and labour plan in voicing the concerns of their members and by monitoring the plan to ensure that obligations are met. ${ }^{250}$

Social and labour plans can help with saving jobs and the up-skilling of workers. Currently, these plans focus on job losses related to mine closures but can be expanded to incorporate job losses as a result of automation and operational requirements. Non-compliance with the social and labour plan should result in stricter sanctions to ensure promises are kept and that the social and labour plan is not drawn up merely for the sake of getting a

239 Manda and Dhaou 2019 Association for Computing Machinery 249.

240 Stats SA Quarterly Labour Force Survey 2018 as cited in Manda and Dhaou 2019 Association for Computing Machinery 249.

241 Manda and Dhaou 2019 Association for Computing Machinery 249.

242 World Economic Forum The Future of Jobs Report 12.

243 Shook and Knickrehm "Harnessing Revolution: Creating the Future Workforce" 2017 Accenture Strategy as cited in World Economic Forum The Future of Jobs Report 7 and 12.

244 World Economic Forum The Future of Jobs Report 10.

245 World Economic Forum The Future of Jobs Report 10.

246 Smith "Govt Must Work With Business, Unions to Create Jobs - Gareth Ackerman" https://www.fin24.com/Companies/Retail/govt-must-work-with-business-unions-tocreatejobs-gareth-ackerman-20190331 (accessed 2019-08-27).

247 World Economic Forum The Future of Jobs Report 14.

248 McKinsey \& Company Skill Shift: Automation and the Future of the Workforce as cited in World Economic Forum The Future of Jobs Report 14.

249 Heald Why Is Collective Bargaining Failing in South Africa? 56

250 CALS "Social and Labour Plan Mining Community Toolkit" https://www.wits.ac.za/media/wits-university/faculties-and-schools/commerce-law-andmanagement/research-entities/cals/documents/programmes/environment/resources/ SLP\%20Community\%20Toolkit\%202\%20March\%202017.pdf (accessed 2019-08-11) 11. 
mining right but benefits workers whose jobs are threatened by automation. Job losses in 4IR will put a strain on the Unemployment Insurance Fund as large-scale pay-outs will create problems in the system. Youth unemployment needs to be addressed if political unrest and violence are to be avoided. ${ }^{251}$ The situation will be aggravated if there is little effort to re-skill and retrain employees, and so it is necessary to invest in such programmes and it is vital that they run the whole life span of employment. ${ }^{252}$ Businesses and employees need to play an active role in retraining and re-skilling and employees must be involved in a lifelong learning plan. ${ }^{253}$

\section{CONCLUSION AND RECOMMENDATIONS}

\section{Recommendations}

\section{Collective bargaining and strike action}

It is recommended that a good collective bargaining system be in place to consider the views and opinions of all. Collective bargaining should be compulsory in situations where an employer considers automating their business.

The LRA and other laws should be developed to cater for individual bargaining as there is a change from full-time to part-time employment.

More role players, such as academics, should be included in social dialogue ${ }^{254}$ as they could offer an unbiased opinion in finding solutions to problems that are not apparent to those directly involved. Worker participation should be encouraged, especially in situations dealing with technological change that directly affects them.

Multimedia platforms and the Internet are a means of assisting collective bargaining and negotiations as well as organising labour. ${ }^{255}$ It allows the collective bargaining process to take place anywhere and leads to an easing of communication barriers during negotiation.

With the possibility of trade unions being obsolete in the future, their role needs to be revisited and perhaps afforded greater protection in terms of legislation.

Strike actions might increase, and workers might be retrenched based on operational requirements. In this regard, workers may need greater protection from retrenchment. Legislation needs to be enacted that would make it difficult for employers to replace employees who take part in a protected strike from being replaced by automation. The definition of the term "strike" needs to be reconsidered and be extended to the circumstances of employees who work from home and to temporary employees. It can be achieved by extending the definition of "employee" as

\footnotetext{
Heald Why Is Collective Bargaining Failing in South Africa? 13.

Ibid.

Heald Why Is Collective Bargaining Failing in South Africa? 129.

254 ILO A Reflection on the Future of Work and Society 9.

255 Heald Why Is Collective Bargaining Failing in South Africa? 40.
} 
well as "strike" to accommodate workers who do not fall under the traditional definitions covered in the LRA.

\section{Occupational health and safety}

It is recommended that new models of risk analysis be created to monitor and prevent occupational health and safety risks. ${ }^{256}$ Consideration needs to given to new management standards that are flexible and agile. ${ }^{257}$ Workers should be included in occupational health and safety management. ${ }^{258}$ Mining companies should have an in-house framework for occupational health and safety ${ }^{259}$ to detect risks on time. A common value system should guide health and safety issues. ${ }^{260}$

A system, preferably online, should provide information on health and safety risks and make it possible for mine owners to obtain information from other mines.261 Temporary workers need to be included in the ambit of occupational health and safety legislation and they need to be made aware that they are covered by the legislation.

Mental health issues will be common in the workplace and need to be addressed in legislation. ${ }^{262}$ Employers will need to develop ways to deal with mental health issues. It will be necessary to consider the matter of responsibility in the case of technological malfunction in order to control the burden on compensation funds. There should be a fund that compensates employees if they are injured operating new machinery. Lastly, a universal labour guarantee needs to be enacted to ensure the workplace is safe and healthy ${ }^{263}$ as workers may be jeopardised if pressed to reach a certain target by methods perhaps not in compliance with regulations.

\section{Skills development}

A process needs to be in place that assists in employment creation in 4IR. ${ }^{264}$ Temporary employees' income should be made more predictable. ${ }^{265}$ Wages should not be negatively impacted by $4 \mathrm{IR}$. Key role players need to consider what skills will be needed and develop programmes that supply those skills. ${ }^{266}$ Existing workers need to be retrained and re-skilled if they are to keep their jobs. The SDLA will need to be revisited and new guidelines on

256 Badri et al 2018 Safety Science 405.

257 Badri et al 2018 Safety Science 408.

258 Bluff et al OHS Regulation for a Changing World of Work 45 and 49.

259 Badri et al 2018 Safety Science 407.

260 World Economic Forum Values and the Fourth Industrial Revolution http://www3.weforum.org/docs/

WEF_Values_and_the_Fourth_Industrial_Revolution_WHITEPAPER.pdf (accessed 201810-11) as cited in Chia et al 2019 American Journal of Industrial Medicine 278.

261 Badri et al 2018 Safety Science 408.

262 Leka and Jain 2010 World Health Organization 136 as cited in Badri et al 2018 Safety Science 407.

263 ILO Global Commission on the Future of Work 38.

264 Heald Why Is Collective Bargaining Failing in South Africa? 42.

265 Heald Why Is Collective Bargaining Failing in South Africa? 35.

266 Manda and Dhaou 2019 Association for Computing Machinery 246. 
funding for training provided. Trade unions can negotiate the retraining of all workers. Job losses on the mines should be mitigated by specifically directed training programmes but should not be restricted to mine-related skills. This can be done in terms of a social and labour plan.

There should be investment in developing highly skilled workers and the programmes should take a long view by equipping workers with skills that are flexible and agile. Education systems should provide training, easing the burden on employers and offering a focused structure.

Key role players need to be involved in job creation and in deciding how the goal is to be achieved. ${ }^{267}$ Businesses and employers need to be involved in the retraining and re-skilling of employees 268 and employment programmes should be implemented by government. ${ }^{269}$

Government needs a financing mechanism that pays workers when they undergo training. Alternatively, workers could be entitled to a certain number of training rights. ${ }^{270}$ Workers need support during the transition to 4IR and there should be investment in institutions, policies and strategies that provide support. ${ }^{271}$

Older workers should have a choice as to whether they wish to be economically active or not and working conditions should be favourable for their continuing to work. ${ }^{272}$ SETAs can identify the specific skills needed in the mining sector and implement the relevant skills-development plans.

A new fund should be established to pay for the training and re-skilling of workers, and employers that plan on automating should contribute to it. The fund should be provided for in separate legislation and contain detailed provisions on its funding and what type of training and learning it will finance, thus lessening the burden on SETAs. The training and learning financed by the fund should be aimed at skills needed in 4IR.

Lastly, the Department of Labour should offer services to vulnerable workers; automation has the potential to make most mineworkers vulnerable and in need of the assistance envisaged in terms of the Employment Services Act 4 of 2014. ${ }^{273}$ This Act should be used to benefit all workers who lose their jobs and specific programmes for mineworkers should be developed.

\section{Conclusion}

South African labour legislation covers numerous aspects that impact labour relations and the workforce. It makes sufficient provision for collective

267 Smith https://www.fin24.com/Companies/Retail/govt-must-work-with-business-unions-tocreatejobs-gareth-ackerman-20190331.

268 Heald Why Is Collective Bargaining Failing in South Africa? 129.

269 ILO Global Commission on the Future of Work 32.

270 ILO Global Commission on the Future of Work 31.

271 ILO Global Commission on the Future of Work 32.

272 ILO Global Commission on the Future of Work 33.

273 The aims of the Employment Services Act (ESA) include providing for public employment services; finding ways to promote employment of young work seekers and vulnerable persons; and helping people retain their employment in distressed companies. 
bargaining and strikes, occupational health and safety and skills development. However, the laws are not implemented in a way that gives full effect to the purposes of such legislation. Role players lack the knowledge and expertise needed to carry out the law. The arrival of $4 \mathrm{IR}$ will bring many changes to the world of work that need to be taken into consideration in examining the current legislative framework. This study has found that 4IR will impact the labour laws in the mining sector and that changes will need to be made in order to protect workers.

The reality of 4IR will have an impact on the future world of work, which can either be positive or negative depending on whether the role players are proactive in finding solutions to the problems that the mining sector labour force faces. For that reason, it is important to consider seriously the findings of this analysis and its recommendations. 